\title{
A record of the brain fungus, Calvatia craniiformis (Schwein.) Fr. ex De Toni (1849) (Basidiomycota: Agaricaceae) from Maraylya, New South Wales, Australia
}

T.J. Hawkeswood*

PO Box 842, Richmond, NSW, 2753, Australia

${ }^{*}$ Corresponding Author

T.J. Hawkeswood

Article History

Received: 25.06.2019

Accepted: 14.07 .2019

Published: 30.07 .2019

\begin{abstract}
In this note, the brain fungus, Calvatia cranifformis (Schwein.) Fr. ex De Toni (1849) (Basidiomycota: Agaricaceae) is recorded from Shale Sandstone Transitional Forest (SSTF) at Maraylya, New South Wales, Australia. The fungus was represented by three basidiocarps in two clusters of two and one fungal body pushing through leaf litter on the side of a rarely used four wheel drive track on private property. The vegetation of the site is described. A brief comparative review is provided on the biology and human use of the fungus in other countries where it occurs, viz. USA and India.
\end{abstract}

Keywords: Calvatia craniiformis, Agaricaceae, Maraylya, New South Wales, Shale Sandstone Transitional Forest, vegetation description, Australia, use by American Indians, hemostat

\section{INTRODUCTION}

Calvatia craniiformis (Schwein.) Fr. ex De Toni (1849) (Basidiomycota: Agaricaceae) is a distinctive and bizarrely shaped fungus which has been detected in many countries, e.g. USA [1], [2] ,[3], Mexico [4], Japan [3],[5] India [6], [7] Indonesia [8] Malaysia [9] South Korea [10] and China [9] indicating a widespread distribution in the northern hemisphere, except for Australia [9]. It is commonly known as the Brain Puffball or Skull Puffball because of the strange morphology of the basidiocarps and hence the scientific epithet [9] (see Figs. 1,2 of this paper). The fruiting body of the fungus consists of a gleba (or head) and a short pseudostipe; the turbinate head measures 50-160 mm in diameter [3]. The gleba is lobed and smooth at first but the upper surface develops into indentations and grooves and the whole head resembles a human brain; the spore mass is white with a slight yellowish hue at first [3], [11]. Virtually nothing has been described of its ecology in Australia.

\section{OBSERVATIONS}

During the afternoon of 6 July 2017 [1350 hrs, AEST time], I was inspecting some property in Cattai Ridge Road, Maraylya, New South Wales [33.583524 S,150.9324563 E] for flora and fauna. I suddenly noticed three basidiocarps of a peculiar fungus (resembling small human brains!) protruding through the leaf litter on the side of a rarely used four wheel drive track and all fruiting bodies were young in good condition. They had probably emerged a day or two previously after heavy nightly rain in the area. The three basidiocarps were photographed (Figs. 1, 2) and identified as Calvatia craniiformis (Schwein.) Fr. ex De Toni (1849) from various Internet resources. No other fungi were detected in the area. The vegetation of the surrounding area is one of Shale Sandstone Transitional Forest (SSTF). This was the first time I had observed this fungus in over 50 years of exploration in the Blue Mountains and other sandstone areas of Sydney. The following plant list was obtained during the course of several hours on the site (only native species listed): Pteridium esculentum (Dennstaedtiaceae), Pellaea falcata (Pteridaceae), Cheilanthes sieberi (Schizaeaceae), Cassthya glabella (Cassythaceae), Casuarina littoralis (Casuarinaceae), Ceratopetalum gummiferum (Cunoniaceae), Elaeocarpus reticulatus (Elaeocarpaceae), Epacris pulchella (Epacridaceae), Breynia oblongifolia (Euphorbiaceae), Glycine clandestina, Hardenbergia violacea (Fabaceae), Acacia floribunda, Acacia linifolia, Acacia longifolia (Mimosaceae), Angophora bakeri, Angophora floribunda, Eucalyptus punctata, Eucalyptus crebra, Kunzea ambigua (Myrtaceae), Notolaea longifolia (Oleaceae), Pittosporum undulatum (Pittosporaceae), Banksia ericifolia, Banksia serrata, Banksia spinulosa, Grevillea banksii, Hakea sericea, Lambertia formosa, Lomatia silaifolia (Proteaceae), Zieria smithii (Rutaceae), Veronica plebeia (Scrophulariaceae), Caustis flexuosa,

Copyright @ 2019: This is an open-access article distributed under the terms of the Creative Commons Attribution license which permits unrestricted use, distribution, and reproduction in any medium for non commercial use (NonCommercial, or CC-BY-NC) provided the original author and source are credited. 
Gahnia erythrocarpa, Gahnia sieberiana (Cyperaceae), Lomandra longifolia, Lomandra filiformis (Lomandraceae), Dianella caerulea, Dianella producta (Phormiaceae), Entolasia marginata, Entolasia stricta, Eragrostis brownii, Imperata cylindrica, Oplismenus aemulus (Poaceae), Smilax glyciphylla (Smilacaceae), Xanthorrhoea australis (Xanthorrhoeaceae).

\section{DISCUSSION}

As regards its general ecology, C. craniiformis has been recorded from open grounds and meadows in India [6], [7]. [3] noted that in the USA, the habitat of $C$. craniiformis was terrestrial with the fungus occurring in open areas, meadows, disturbed areas or in native habitats under Desert Willow (Chilopsis linearis), Mesquite (Prosopis spp., Fabaceae), Oak (Quercus spp., Fagaceae), Pinyon Pine (Pinus edulis, Pinaceae), Juniper (Juniperus spp., Pinaceae) or Sage Brush (Artemisia sp., Asteraceae). For Australia the only recent ecological data I have been able to locate is a note by Leonard [11] who noted the species grows in soil amongst grass on roadside verges but that it is also reported from pasture and parkland habitats. My record was also on a verge of disturbed rarely used four wheel drive track within a highly disturbed area of native Eucalyptus forest. Leonard's record was from Tenterfield, northeastern New South Wales on 8 March 2017 [11]. This locality is over 700 km away from Maraylya.

It is interesting to note that Burk [12] earlier noted that the species was utilized by two north American Indian tribes (viz. Ojibwe and Chippewa) as a hemostat for nosebleeds. However, there appears to be no records of Australian aborigines utilising this fungus for any ailment [13].
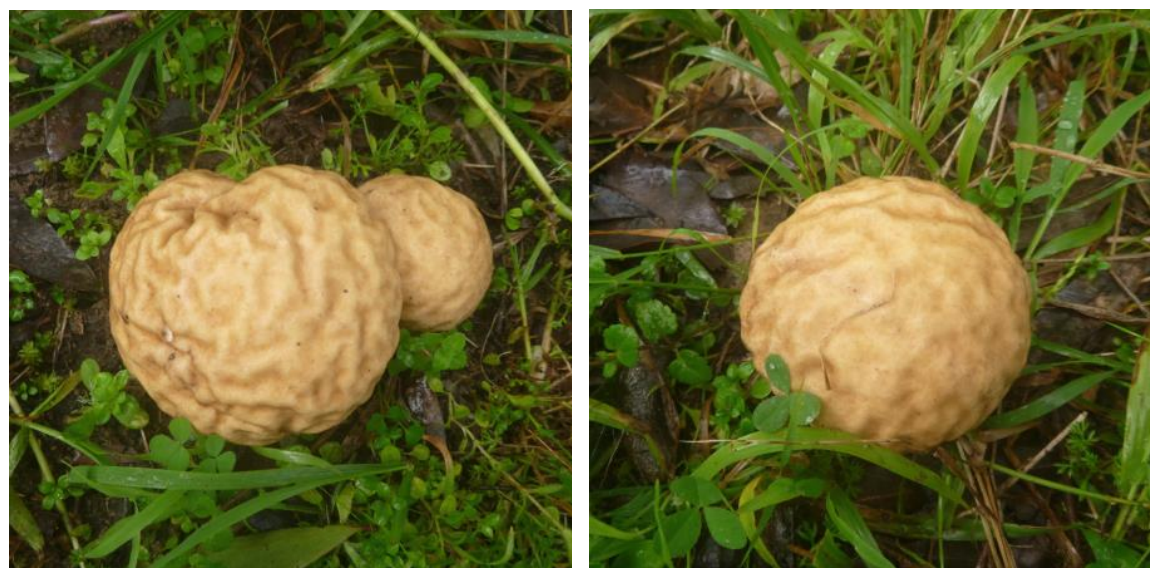

Fig- 1, 2.1 (left). Two basidiocarps of Calvatia craniiformis (Agaricaceae) pushing through leaf litter and small weeds at Maraylya New South Wales, alongside a rarely used vehicular track in Shale Sandstone Transitional Forest. 6 July 2019. (Photograph: T.J.

Hawkeswood). 2 (right). One basidiocarp of C. craniiformis growing near the other two. (Photograph: T.J. Hawkeswood).

These are the first specimens of C. craniiformis (Figs. 1,2) that I have observed in the Sydney district in over 50 years of hiking and exploring throughout the Sydney Bioregion since I was a child in the 1960's. I have not observed the species anywhere else in Australia either. It is interesting to note that Bougher [14] did not record it from the Perth area in Western Australia and Moore \& O'Sullivan [15] failed to describe or photograph it from the Hunter Region of New South Wales. Additionally, the species was not included in Fuhrer [16] or Young [17] either. Hawkeswood [18] also recently recorded a rare species of Phallaceae from Australia which had been rarely if ever recorded from Australia before, Phallus cinnabarinus (W.S. Lee) Kreisel [18]. The Calvatia fungi were growing in a group of three basidiocarps on the side of a vehicular track amongst tiny weeds (Figs. 1,2). The surrounding vegetation is described in the Observations section above. These data on C. craniiformis from Maraylya, New South Wales are recorded here since so little data is available on its ecology and it is unlikely, given its apparent rarity in Australia, that I will encounter it again during my lifetime, hence another reason for publishing the record.

\section{Acknowledgement}

I would like to thank an anonymous referee for reviewing the paper before publication.

\section{Conflict of interest}

There is no conflict of interest regarding this paper. The research was solely funded by the author of this paper.

\section{REFERENCES}

1. Zeller, S. M. (1964). The genus Calvatia in North America. Lloydia, 27, 147-186.

2. Miller, O. K. (2006). North American mushroomsa field guide to edible and inedible fungi (No. 579.6097 M5).

3. Bates, S. T., Roberson, R. W., \& Desjardin, D. E. (2009). Arizona gasteroid fungi I: Lycoperdaceae (Agaricales, Basidiomycota). Fungal Diversity, 37, 153. 
4. Esqueda, M., Sánchez, A., Rivera, M., Coronado, M. L., Lizárraga, M., \& Valenzuela, R. (2009). Primeros registros de hongos gasteroides en la Reserva Forestal Nacional y Refugio de Fauna Silvestre Ajos-Bavispe, Sonora, México. Revista mexicana de micología, 30, 19-29.

5. Hosaka, K., \& Uno, K. (2012). A preliminary survey on larval diversity in mushroom fruit bodies. Bulletin of the National Museum of Nature and Science Series B, Botany, 38, 77-85.

6. Abrar, S., Swapna, S., \& Krishnappa, M. (2008). Bovista aestivalis and Calvatia craniiformis-New Records to India. Journal of Mycology and Plant Pathology, 38(3), 504-506..

7. Verma, R. K., Mishra, S. N., \& Pandro Vimal, T. A. (2018). Diversity and distribution of Calvatia species in India: a new record from central India. International Journal of Current Microbiology and Applied Science, 7(9), 2540-2551.

8. Kasuya, T., \& Retnowati, A. (2006). New or noteworthy species of the genus Calvatia Fr.(Basidiomycota) with probable medicinal value from Indonesia. International Journal of Medicinal Mushrooms, 8(3).

9. Wkipedia (2019). Calvatia craniiformis. https://en.wikipedia.org/wiki/Calvatia_craniiformis (Accessed: 3 July 2019).

10. Jung, H. S. (1995). Fungal Flora of Ullung Island (VI)-on ascomycetous, auriculariaceous, and gasteromycetous fungi. The Korean Journal of Mycology, 23(1), 1-9.

11. Leonard, P., \& Malina, D. (2017). Caught between two worlds: mothers as academics. In Changing the subject (pp. 29-41). Taylor \& Francis.

12. Burk, W. R. (1983). Puffball usages among North American indians. Journal of Ethnobiology, 3, 55-62.

13. Kalotas, A. (2013). Aboriginal use of fungi. https://www.anbg.gov.au/fungi/aboriginal.html (Accessed: 6 July 2019).

14. Bougher, N. L. (2017). Fungi of Perth region and beyond. Western Australian Naturalists' Club (Inc.) Perth, 36pp.

15. Moore, S., \& O'Sullivan, P. (2013). A guide to common fungi of the Hunter-Central Rivers region. Hunter-Central Rivers Catchment Management Authority.

16. Fuhrer, B. (2016). A Field guide to Australian Fungi. Blooomings Books, Melbourne: 1-360.

17. Young, A.M. (2017). A Field Guide to the Fungi of Australia. University of New South Wales Press, Sydney: 1-240.

18. Hawkeswood, T. J. A record of the stinkhorn fungus, Phallus cinnabarinus (WS Lee) Kreisel (1996)(Basidiomycota: Phallaceae) from Arcadia, New South Wales, Australia. Calodema, 708: 1-3. 